aanhourders van 't genegotieercle geweest zijn, en noch ondertekent: Maximiliaan de Jong, ${ }^{1}$ ) de naem van Radia Bougijs ${ }^{2}$ ) in sijn tale, D. van der Straten, Cristiaen Poolman, 't merk van Cap" Joncker, Gerrit den Back ${ }^{3}$ ) en in het Maleijts de naan van dien ${ }^{4}$ ) schrijver.

\title{
CCCXI. MOLUKKEN.
}

\section{Maart 1667. ")}

Saif Oedien, die in 1657 ,alleen door toedoen der .E. Maatschappij” sultan van Tidore was ,gekozen tegen de oude Molukse costumen, en rijk-wetten" en daardoor zijn "ouder broeder, Goranja” van diens rechten had beroofd, was cen ,vorst van veel verstand", maar volgens de onzen ,zeer kregelig, licht-geraakt, en zeer eigen-zinnig". (Vgl. hiervóór, bldz. 338). Niet te verwonderen, dat de O. I. C. er op gesteld was, de verhoudingen zoo scherp mogelijk te regelen, vooral ,in opzicht van de specerijen". Ofschoon reeds vroegrer overeenkomsten met hem waren gesloten, nam men de gelegenheid waar toen deze kwam, om een verdrag te sluiten, ,daar bij een weg gebaant” werd, „om zijne kregeligen aart wat beter, dan wel bevorens, te kumnen temmen". (Valentijn, I, Moluccos, bldz. 106, 109). Deze gelegenheid kwam met Speelman's expeditie tegen Makassar. Van Boeton (zie hiervóór, bldz. 346) vertrok Speelman naar de Molukken en sloot dáár onderstaand verdrag met Tidore. (Stapel, bldz. 96, 118, v.v.), hetwelk Tidore geheel aan de O. I. C. onderwierp.

Articulen ende voorwaarden, waarop den grootmagtigen Ceijfoedijn, coning van Tidor, en sijne Grooten voor haar ende haare subjecten en nacomelingen ter eenre, en den Heere Cornelis Speelman, Superintendent etc", in den name van den Ed. Heer Gouverneur Generael Joan Maatsuijclier ende de Heeren Raden van India, representerende de hoogste magt en authoriteijt van de Generale Nederlandsche Verenigde Geoctroijeerde Oostindische Compagnie in deze landen, ter andere zijden, voor eeuwigh en altoos geaccordeert, verdragen en overeengecomen zijn in maniere als hier onder geschreven.

1) Vg1. Stapel bldz. 96.

2) Aroe Palakka? (Vgl. Stauel, bldz. 106, v.v.).

3) Zie over de onderteekenaars Stapel, bldz. 97, v, 107.

4) "Den":

5) Uit het Contractboek. - Ook bij Valentijn, I, Moluccos, bldz. 109 v.v. 
Gelijk als in clen jaare $165 \%$ tusschen welgemelten heere Coningh en sijne Groote en den heere Gouverneur Simon Cos onderlinge bij monde ${ }^{1}$ ) grecontracteert ende versproocken, zoo sullen alle nagel- ende notebomen als doen uijtgeroeijt en verclorven geworden in alle landen. onder de Tidorese gehoorsaamheijt staande, hetzij ook waar die soude mogen gelegen wezen, geene uijtgesondert, niet alleen uijtgeroeijt en verdorven blijven, nlaar ook ten eeuwigen dage (ten waare het d'E. Compagnie selve begeerden) geene nieuwe aamplantinge mogen geschieden, directelijk ofte indirectelijk, maar sullen noch altoos, ten overstaan van sulcke Nederlandsche gecommitteerden als den heere President claartoe believe te bestellen, noch doorgaans door allen lan(len soo veel visites moeten werden gedaan, als zijn E. kompt nodigh te oordelen, om alle ouwe boomen, die noch in wesen gebleven, ende nieuwe, die uijtgebedt en opgegroeijt mogten wezen, t'elckens wegh te nemen en te bederven.

Ende op dat dit geschiede niet de minste moeijte en bekommeringen, soo werden alle de onderdanen ende inwoonderen der Tidorezen cnde haare territorien verbonden, gelijk sij te rooren oock verbonden sijn geworden, aanwijsinge te doen van alsulcke note- ofte nagelbomen, als noch ergens in de landen mogten sijn staan gebleven, en die sij luijden (naar gedane aanwijzinge) dan oock selver moeten ruineren en omvellen, op pene van indien namaals bevonde wierde hiervan in gehreecke te wesen gebleven, den schuldige claarover rigoreus en te cxempel van andere sal werden gestraft.

Hiertegen blijft de Generale Compagnic verbonden, gelijck sij doen verbonden is geworden, soo lange in dit gecontrackteerde geen infractie off contraventie werden gedaan, jaarlijex aan den Coningh en Grooten voor haar en gemeente van de Tidorese landen, aan deze omvellinge der note- en nagelbonen $g$ 'intresseert, ten behoorlijcker tijt prompt uijt te keeren en te betalen eene somma van drie cluijsent slegte realen van $48 \mathrm{st}^{\text {"si }}$ ofte vier en twintigh honderd $R^{r+n}$ te sestigh stuij" ijder. Sijnde wijders versproocken, overeengekomen ende geaccordeert, dat hooggenelte Coningh en sijne rijx grooten nu noch ten ceuwigen dage niet en sullen vermogen, onder wat schijn ofte titul het soude mogen wezen, in enige van sijne landen, gene uijtgesondert, in te laaten ofte te admitteren, sonder voorweten, expresse licentie. ende toestaan van van de Compagnie, enige Europiaansche of Indi-

1) Ook bij geschrifte? Vgl hiervóór no. CCXXI. 
aensche natien welcke ofte hoedanige die oock wesen of te genaempt mogten werden, 't zij France. Spanjaarden, Portugesen, Engelsche. Deenen, Sweeden, Italianen, Hoogduijtsche of te andere, item Macassaren, Javanen, Bantammers, Atchinders, Solonr- ofte Timoresen, Moren, Bimanezen, gene uijtgesondert.

Van alle welcke opgenoemcle ofte andre natien hij Heere Coningh, noch "Zijne rijckex grooten, in geene van haare landen, oock niet en sullen vermogen te admitteeren eenige gesanten, besendingen ofte brieven, 't zij clan ook onder wat titul, naam ofte schijn het wesen magh, maar gehouden sijn die off en naar herwaarts aan den Gouverneur of te President te wijsen, om aldaar gehoort, haar aanbrengen geexamineert en (soo 't nodigh is) onderlinge gecommuniceerd te werden.

Indien de Compagnie met eenige van de selve natien in vijantschap grerogte, ${ }^{1}$ ) tegen sodanige sal hij Heere Coning ende sijne Groote hun oock vijand moeten verklaren en gehouden sijn tot afbreuck van de sodanige, als het hier om en omtrent te doen is, alle hulpe ende bijstant toe te brengen, sonder dat hij sal vermogen met de sulcke afsonderlijck van vrede te handelen, veel min met deselve eenige alliantie te sluijten, waar tegen de Compagnie oock verbint ende belooft, met alsulcke vianden tot geenigh verband van vrede te komen, ten zij wel gedagten Koninck met alle sijne landen en onderdanen daar in en werde begrepen.

Indien 't geviele, dat van d'eene off d'andre sijcle tot de gemelte heere Coningh ende Zijne landsaten eenige gesanten afquamen van vorsten, waarmede de Compagnie in vijantschap waare, soo sal hij gehouden zijn en belooft het mits desen, deselve gevancleelijk aan de Compagnie over te leveren, sonder de selve te verbergen off haar vlugten te mogen faciliteren, veel min te conniveren.

Wijders verclaren opgenoemcle heere Coningh encle zijne Groote hun zelve, hare landen ende onderdanen te stellen en over te draagen in handen ende onder bescherminge van de generale Compagnie, dezelve mits desen erkennende voor haare schut- en scherm heer, ja sodanig, dat of t'eniger tijt quame te gebeuren, clat enige Europiaense of Indiaense natien met off tegen haaren dank begeerden of poogden possessie of besittinge in enige haare landen te nemen, de Compagnie sonder de alderminste contradictie van ijmanden dat selve zal vermogen te verhinderen, verbieden en voorkomen, evensoo als in haar

1). Geraakte. 
vrije eijgen landen, greene andre toebehorende, ende in welcken gevallen wij bij desen verclaren, de selve in sulcken eijgendom de Compagnie toe te behoren, gelijk wij ook met al ons vermogen en magt die nevens de Compagnie solanig beloven te bewaren.

Ende op dat in dese goede overeenkomste en euwighdurend verhond door den desen tusschen de Coningh ende de generale Compagnie opgerecht, t'eeniger tijt bij versterff off andersints geen scheuringe, breucke ofte verwijderinge mogte opkomen, zoo is versproocken ende geaccordeert, dat bij versterff van de hoogh gemelte Coning (die Godt de Heere een langdurig leven gunne) de rijxgrooten geenen successeur tot de croone sullen vermogen vast te stellen sonder toestemmingh en met advijs van de Compagnie, dat is te verstaan van den genen, die wegens de Compagnie als dan hier sal presideren, also de Compagnie door desen contracte wert ingelaten tot een lidt en medegenoot in cle Tidoreese rijckx regeringe.

Soo het de Compagnie goetdunckt. son sal hij tot haare meerder verseeckeringe van desen contracte en soncler enig tegenspreecken mogen vorderen soodanige personen van aansien, om tot ostagiers aan 't Casteel soo langh als nodigh geacht wert te resideren als alsclan de saack kompt te vereijsschen, behoudens dat de soodanige door off van wegen de Compagnie in haar gelove niet geturbeert, maar allen 't halven wel ende behoorlijck getracteert sullen werden.

Het sal de Compagnie vrijstaan allerwegen, daar zij het kompt goet te vinden, op de landen ende territorien van het Tidorees gebied te extrueren sulke vastigheden als in tijde en wijle vereijst mogte werden, en oock deselve weder in te trecken, naar gelegentheijt van tijt en saacken.

Oft gebeurde dat enige Europiaense off inlandse Compagniedienaren, vrijburgers, mardijckers, slaven ofte andre onderdanen van de Compagnie, on eenige begane misclaat ofte andre duijvelsche hoosheijt, sigh van onder de Compagnie onttrecken en op de vlugt begeven mogte, sulcke, in dien se komen onder de Tidorese jurisdictie, sullen terstont gevat, ende hier aant Casteel in verseeckeringe gebragt werden, doch soo enige Tidorese contrarie dese soo eene quame te verbergen ofte te verswijgen, sal hij daar over strafbaar zijn en niet verschoont mogen werden.

Ook en sullen geene Hollanderen ofte andre dienaren van de Compagnie, tot de Tidorese overkomende, van het Christen gelooff af te gaan, ende de wet van Mahomet, aen te nemen, geensints mogen aangenomen, verswegen, geherberght ofte verschoolen, maar stonts- 
aan overgelevert moeten werden op peene van sware straffen, sooenige der Tidorese onderdanen contrarie desen quamen te doen, en soo weder van Compagnies zijde.

Indien eenige dienaren off onderdanen van de Compagnie door die van Tidore quam beledight, verkort ofte andersints misdaan te werden; soo sullen des Compagnies officieren de selve vermogen in d'ijsers te sluijten, om an den Coningh van Tidoor daarvan kennis gedaan, en als wanneer door Zijn Hoogheijt gecommitteerde gestelt sullen werden, on de saack te examineren, ende daar over de welvercliende straffe ge executeert te werden. Indien weder enige Tidoresen van Compagnies dienaren ofte onderdanen benadeelt, ofte misdaan quame te werden, die sullen oock mogen geapprehendeert, maar voors ten eersten aan den heer President moeten overgelevert werden, als wanneer dan mede sijne welverdiende straffe naar bevindinge van de saack niet en sal ontgaan.

Om goede consideratien is mede verstaan ende besprooken, dat de Papaouse eijlanden, voor sooveel die onder de gehoorsaamheijt van den coningh van Tidoor sorteren, alleen door sijne onderdanen sullen bevaren worden, behoudens clat hij heere Coningh oock belooft en aanneempt, indien de Compagnie t eeniger tijt van ginder parthije slaven off ietwes anders quame te begeren, hij die door de zijne voor de Compagnie sal moeten laten handelen, sonder daaraan enigh voordeel te doen, gelijck het de Compagnie sal vrijstaan, haren dienst ofte de gemene saack sulcx vereijsschende, derwaarts met haare scheepen besendinge te doen, doch niet sonder voorgaande kennis en kuntschap van den Koningh.

De vaart op Mindanauw ende andre eijlanden, dat uijt gelegen, ${ }^{1}$ ) sal sodanigh als tot noch toe en sonder d'een off d'ander van onse srealieerde te prejudiceren, mogen onderhouden werden, soo lange de Compagnie daarin voor haare en de gemene welstant niet nadelighs oordeelt te resideren en waarom het oock de Compagnie sal vrijstaan, indien $\mathrm{t}$ haar nodigh dunckt en sodanigh ten goede verstaan wert te behooren, de selve te verbieden, ende te doen naarlaten.

Naar Amboina, Banda ende alle andre territorien, onder de gehoorsaamheijt van de Compagnie, oock naar Bouton, Macassar, Tiema, ${ }^{2}$ ) Biema, Javaanse Cust, Bantam etc ${ }^{2}$ en sullen de Tidoresen geene besendinge doen, of $f$ derwaarts heene met haare vaartuijgen varen mogen, ten zij met expresse licentie van de Compagnie.

1) Waarschijnlijk beteekent dit: ,dien kant uit gelegen".

2) Timor. 
Aangesien de Paponers door haar continueel roven verscheijde onenigheden nu ende dan hebben komen te veroorsaacken, soo heeft oock den Koningh belooft ende aangenomen. voor soo veel die onder sijne gehoorsaamheijt sorteren, daar in sodanige ordre te stellen, dat het na desen niet meer en come te greschieden, zijn de te dien einde voor eerst verstaan, dat sij nergens sullen vermogen te vaaren in en om de landen, met de Compagnie ende Moluxse bontgenoten in vrintschap zijncle, oock niet indien eenige daarvan weder in vijandschap afvielen, ten zij alvoren hier aan 't Casteel van clen Gouverneur of President een acte van licentie komen vorderen, gehouden hlijvende, wanneer van de reijse retourneren, die alhier weder te restitueren: en sullen alle degeene. welcke desen contrarie doen, onvermijdelijck met de doot moeten werden gestraft, boven restitutie van de goederen, die men zal bevinden door haar gerooft te zijn.

Aldus gecontracteert, over eengecomen ende verdragen, mitsgaders op de Mahometaanse wijse besworen, int Casteel Orangje op Maleija, den 29 Maart $\mathrm{A}^{\circ} 1667$, bij voorschreven heere Coningh, geadsisteert met Banouassij, Rijx hoccum, quimelaha Doaux ${ }^{1}$ ) van Soasiwo, ${ }^{2}$ ) Caboul, quimelaha van Togohia, ${ }^{3}$ ) Sousousou, quimelaha van Mare ${ }^{4}$ ) ofte Pottebacken, ${ }^{4}$ ) Alie, (quimelaha van Tommewaij, ${ }^{5}$ ) Jegoene, quimelaha van Toma, ${ }^{(i)}$ Idij, segnadie quimelaha van Toloa, ${ }^{7}$ ) oock met eene representerende de presentie van den Goegoegoe, Jan Jau Aleij, Toelol, Capitein Laut. sengnadia rijx hoecom. Sabba, quimelaha van Samaffo, Codapay, quimelaha van Sokonaero, Samaeija ${ }^{8}$ ), sengnadie van Marieco, ${ }^{9}$ ) Soatia Casjoeba, sengnadie van Marieco, Soatij Doeco, (quimelaha van Tomaijdi; ${ }^{10}$ ) roorts noch alle de andere Grooten, on indispositie en andre ongelegentheden niet zijnde konnen herwaarts komen. Ende van wege de

\footnotetext{
1) Valentijn heeft, vermoedelijk beter, „Doauw”.

2) Soasioe op Tidore, ,verblijfplaats van den Sultan”. (Veth, Woordenboek. III, bldz. 958).

3) Valentijn, bldz. 111, heeft „Togalika”.

4) Valentijn heeft ten onrechte "Motir". Marek of Pottebakkerseiland ten Z. van Tidore.

5) Valentijn heeft "Tommewaak" = Tommelau, volgens Veth op de Z.O.kust van Tidore?

(6) Valentijn: „Tama”.

i) Válentijn: „Taloa”.

8) Van Jan Jau Aleij tot hier toe zijn de namen volkomen onzeker (vgl. Valentijn).

9) Marikoe op Tidore.

10) ?
} 
Compagnie door den Superintenclent, ten overstaan ende bijwesen van den president Maximiliaen de Jonge, den opperkoopman Danckert van der Straaten, den capiteijn Christiaen Poolman. ${ }^{1}$ )

\section{MAKASSAR.}

\section{Maart 1667. $\left.{ }^{2}\right)$}

Een der middelen, om Makassar in het nauw te brengen was, de omliggende kleine eilanden voor de O. I. C. te verzekeren. O.a. werd daarbij het oog geslagen op Moena (Pantsiano) en wel vooral op het ,leelijke roofnest Tibore" op de Noordkust. Dit werd den 29 Maart tot onderwerping gebracht. (Stapel, bldz. 115, 124, v.; Dagh-Register 1666-1667. bldz. 274).

Accoortbrieff tusschen den conink van Tiboor ende d'E. Compagnie ende hem dese naevolgende poincten voorgestelt door radia Pallacca ${ }^{3}$ ) ende clen capiteynIuijtenant Davit Steijger, ${ }^{*}$ ) uijt de naam van d'E Hee: Cornelis Speelman, admiraal en veltoverste, mitsgaders superintendent, commissaris over de Moluxe eijlanden \&:".

1.

Dat hij sal sijn geweer over geven en sigh op genade en ongenade met al die gene die bij hem sijn of al wat onder hem staat ook dat selvige doen sal op de discretic van de Compagnie.

\section{2.}

Dat hij alle Maccassaren, die hij hem zijn of op het land van Pantsiano of claar ontrent, (laar hij wetenschap van had, bij ons brengen, dood of levendig, en soo de conink van Tiboor sig daar niet mans genoeg toe vind, sal hij schuldig sijn, om aan ons te waarschouwen, dan sullen wij daar in remedie stellen.

3.

Zal den coningh van Tihoor niet jijden of toestaan, datter enige

1) Bij Valentijn, bldz. 111, volgt hier nog: „onderstond, gecollationeert, accordeert, in 't Kasteel Orangie, Ultimo Maart 1667. Was geteeckent Abraham Gabbema, Secretaris".

2) Uit het Contractboek.

3) De bekende Aroc Palakka.

4) Zie over hem Stapel, bldz. 117, 125. 